\title{
観光地・上高地の形成過程と国 THE DEVELOPMENT PROCESS OF 際観光委員会における議論 KAMIKOCHI AND DISCUSSIONS IN THE COMMITTEE OF TOURIST INDUSTRY
}

砂本文彦 $-* 1$

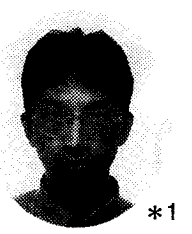

Fumihiko SUNAMOTO

In 1930, the Government established the Board of Tourist Industry and the Committee of Tourist Industry to attain foreign currency. They had discussed what they should do to construct resorts for foreign tourists, and chosen intensive resort area. The aim of this paper is to make clear states of developments of Kamikochi, where they had chosen.

Developments of Kamikochi had begun opening ground and road for power stations. Therefore, members of the Board and Committee had regarded Kamikochi as a mountain resort. They, especially Gyoji Arai and Kishichiro Okura, had tried to promote to improve roads and a hotel.
キーワード :

上高地，国際観光委員会，宿泊施設，道路
Keywords :

Kamikochi, Committee of Tourist Industry, Hotels, Roads
1.序

1.1 はじめに

1930 年代は悪化していた対外貿易収支を改善するための外国人 観光客誘致が注目されていた時期であり、彼らを受け入れるための 観光地整 備が要請されていた。本報告で取り上げる上高地もその例 外ではなく、少数の登山者のための「秘境」から、「国際観光地」への脱 皮が期待されていた。この議論の顛末は著者が入 手した国 際観光委 員会 ${ }^{12}$ 会議議 事録 ${ }^{21}$ に克明に記録されている。

本報告は関連文献から 1920 年代から 30 年代にかけての観光地. 上高地の形成過程を把握し、その要因を明らかにするとともに、国際 観光委員会の会議議事録に収められている上高地の観光開発に関す る委員の発言 ${ }^{3)}$ を分析することで、上高地の観光 開発 と国際観光政 策との関連性を明らかにするものである。現代においても代表的な 観光地である上高 地の観光 開発の軌 跡を辿ることは、今後の国際規 模に展開するリゾート開発に適切な方向性を与えると思われる。

\section{2 上高地前史}

標高 $1,500 \mathrm{~m}$ に位置する上高地が観光地として注目を浴びるのは、 英国人宣教師ウォルター・ウェストンが記した『日本アルプス-登山 と探検』といわ执るウェストンは 1891 年に徳本峠を越えて上高地 に辿り着き、その風景を多くの人々に紹介するきっかけとなった。ウ エストンは牛番小屋に宿泊したと記述しているように、当時の上高 地では人里離れたそのなだらかな地 形を利用して放牧が 行われ、観

*1 高知工科大学工学部社会システム工学科 助手・修士 (工学)

( 782 高知県土佐山田町宮，口）
光地としての性格は乏しかった。上高地はもともと「神河内」上河 内」と呼ばれ、1906 年に加藤敂吉が開設した上高地温泉を端に、現在 の観光地のイメージを醸し出す「上高地」と記述されるようになった 4)。上高地へ注徳本峠越えのルートしかなく、当時は専ら登山準備地 としての価値が見出されていたに過ぎない。

\section{2. 観光地「上高地」形成への背景 2.1 雪源開発に伴う道路整備}

上高地が観光地としてのポ テンシャルを高めるのは，長距離送電 の可能となった 1910 年以降の電源開発 (ダム $\rightarrow$ 水力発電)に伴う道 路整備が契機となっていた。当時は都市 部の電力需 要の増加から日 本中の溪谷がダム建設候補地として計画され（上高地、十和田、黒部、 帝釈峡等)、上高地周辺も水力発電所建設のための道路整備が進ん

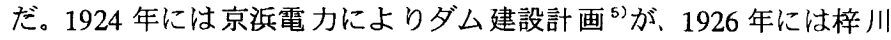
電力による計画が打ち立てられた ${ }^{6)}$ 。

1920 年代後半からは、ダムサイトへ向けての道 路建設が行われ、 島々一奈川渡間には京浜電力により、奈川渡一大正池間は梓川電力 により取り組まれた（図 1、図 3)。この道路開通により、1929 年から 比較的広幅員であった島々ー中ノ湯間に乗り合いバスが蓮転を始め 7)、上高地へのアクセシビリティは飛躍的に向上し、多くの観光客が 訪れるようになった。電源開発に伴う道 路整備が上 高地の観 光地化 に拍車をかけたのである。
*1 Research Assoc., Dept. of Infrastructure Systems Eng., Faculty of Engineering, Kochi Univ. of Tech., M. Eng. 


\section{表 1 上高地観光開発関連年表}

\begin{tabular}{|c|c|c|}
\hline 西暦 & & 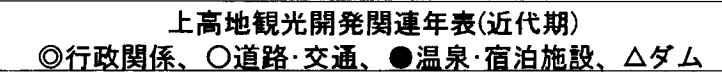 \\
\hline 1884 & & 奥原甚三他四人による上高地牧場が開設 \\
\hline 1890 & & このころより上高地で牛馬の放牧が行われる \\
\hline 1892 & & ウォルター・ウェストンが上高地を訪問 \\
\hline 1904 & 0 & 加藤惣吉が上高地温泉を開設 \\
\hline 1906 & & 株式会社上高地牧場設立 \\
\hline 1912 & 0 & 河童橋畔に旅館養老館開業（五千尺旅館の前身） \\
\hline 1915 & & 焼岳噴火により梓川が堰き止められ、大正池ができる \\
\hline 1916 & (C) & 上高地一帯が保護林に指定 \\
\hline 1918 & ○ & 上高地内梓川右岸沿いの道を上高地温泉株式会社が造成 \\
\hline 1921 & () & 国立公園候補地調查（内務省） \\
\hline & & $\begin{array}{l}\text { 帝国議会に「長野県下上高地二国立公園設置ノ請願」(貴 } \\
\text { 族院)、「上高地国立公園設置)請願」(衆議院)を提出。 }\end{array}$ \\
\hline 1922 & & $\begin{array}{l}\text { 衆議院にて「日本アルプス山中上高地(神河内) 二国立公 } \\
\text { 園設定二関スル建議」が行われた。 }\end{array}$ \\
\hline 1923 & & $\begin{array}{l}\text { 旅館清水屋が上高地温泉から独立営業開始 } \\
\text { 中ノ湯温泉開業 }\end{array}$ \\
\hline 1924 & & $\begin{array}{l}\text { 京浜電力が上高地河童橋付近にダム建設計画立案 } \\
\text { 庭園協会がダム建設に反対して「上高地国有保護林 } \\
\text { 内貯水池設置二関スル意見」書を大臣、知事に提出 }\end{array}$ \\
\hline 1925 & $\triangle$ & 上高地問題研究会設立 \\
\hline 1926 & $\triangle$ & 梓川電力がダム建設計画立案 \\
\hline 1927 & ○ & $\begin{array}{l}\text { 日本新八景に指定 (主催東京日日新聞社、大阪毎日新聞社 } \\
\text { 梓川電力により沢の渡一上高地間に九尺幅の道路建設 }\end{array}$ \\
\hline 1928 & (a) & 上高地一帯が名勝天然記念物に指定（内務省） \\
\hline 1929 & 0 & 水力発電用道路が中ノ湯まで䇋工し、バス運転開始 \\
\hline 1930 & (a) & 国際観光局、国際観光委員会設置 \\
\hline 1931 & (C) & $\begin{array}{l}\text { 「山の座談会」開催 } \\
\text { 国立公園法制定 }\end{array}$ \\
\hline 1933 & (O) & $\begin{array}{l}\text { 大藏省資金の融資を受けた上高地観光ホテル開業 } \\
\text { 合バスが上高地まで乗り入れ開始 }\end{array}$ \\
\hline 1934 & & $\begin{array}{l}\text { 上高地牧場閉鎖 } \\
\text { 上高地一带が中部山岳国立公園に指定 }\end{array}$ \\
\hline
\end{tabular}

*本表は脚注・参考文献欄の記述をまとめて作成したものである。

\section{2 国立公園候補地と日本新八景の選定}

電源開発に伴う道路整備というハード面だけでなく、上高地の名 声を高めていく動きが起こった。1921 年に活発になった上高地への 国立公園指定へ向けての動きである。同年の第 45 回帝国議会には、 貴議院に「長野県下上高地二国立公園設置ノ請願」、衆議院に「上高地 国立公園設置ノ請願」が提出され、翌年には衆議院にて「日本アルプ ス山中上高地 (神河内) 二国立公園設定二関スル建議」が行われた 政府側も同年から内務省衛生局による国立公園調查を開始し、上高 地は最初に調查が行われた ${ }^{9}$ 。後にまとめられた『国立公園候補地 調查概要』101によると、上高地の国立公園としての素質は「天下ノ 絶勝」で「本州ノ中央二当リテ東京、大阪ヨリ等シキ距離」にあると、 その固有の景観と地理条件の良さが指摘され、「最モ適当ナル候補地 ノ一タルヨ失ハズ」とされ、国立公園に指定されるのも時間の問題で あった ${ }^{11}$ 。上高地におけるこのような動きは、国立公園の目的、「… 我力゙国天与ノ大風景 $习$ 保護開発シ...国民ノ保健休養…外客誘致二

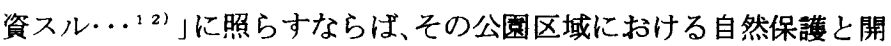
発という一見相反する側面を持ち合わせることとなり、上高地の風 景保護が課題となる反面、外客を受け入れる国際観光地建設の場と して脚光を浴びるという皮肉な効果をもたらすものだった。

だが、こられの国立公園指定に向けて動いていた 1920 年代に、そ の後の上高地の観光地形成に直接的な影響を与えた具体的な施策が 行われたとは言い難い。その一因としては国立公園行政から施策が 本格的に行われるには、1931 年の国立公園法制定を待たなければな らなかったことがあると思われる ${ }^{13)}$

他にも、日本の観光地を認識させる動きとして 1932 年の日本新八 景の選定 ${ }^{14)}$ を挙げることができる。日本新八景とは新聞社が主催と なった観光地ランキングで、国民的なブームとなった。その内容は 「山岳、溪谷、瀑布、温泉、湖沼、河川、海岸、平原につき、各景ごとに推 薦投票、最高点順十位づつを候補地」として、審查員会と一般投票に より決定し、「昭和の新時代を代表すべき新日本の勝景」を選定しよ うとしたもので、上高地は渓谷部門で日本新八景の座についた。この ことからも推察されるように観光地・上高地は既に国民の間にその 存在が認識されていたのであり、日本新八景の選定をうけて更にそ

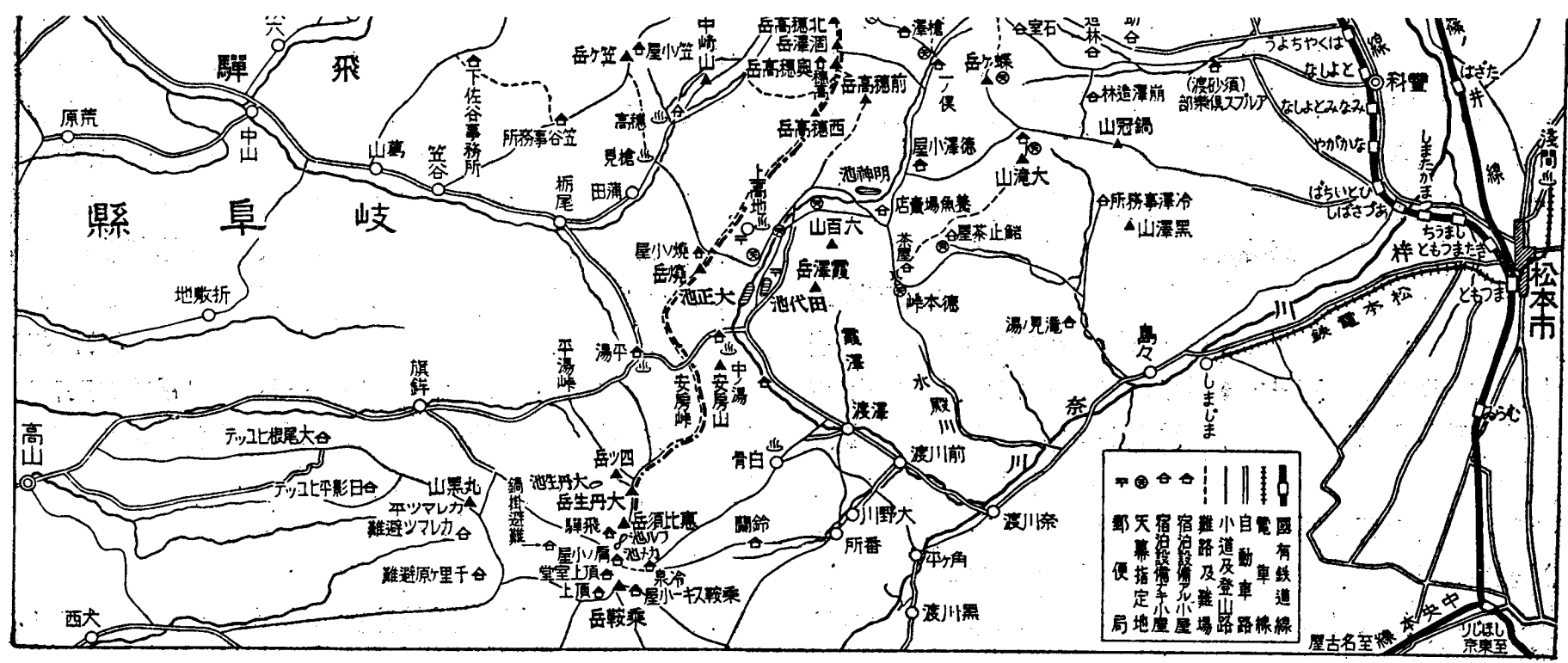

図1上高地周辺図 出典: 鉄道省:鉄道旅行案内「日本北アルプス」, 1936 
の存在は知られることとなったのである。このような結果に到った のはひとえに、前述の道路整備によるアクセシビリティの改善が、登 山者を招き入れ、その見聞録が広く伝えられたことによる。

\section{3. 国際観光委員会議事にみる上高地観光開発思想 3.1 国際钼光政策における上高地開発の意諩と施設整備項目}

国際観光委員会の議事録によると、委員会では外国人観光客誘致 のための重点整備を促進する優先順位付き (ABC ランク)の重要観 光地点リストを作成していた ${ }^{15)}$ 。リスト中、上高地は B ランクに位 置づけられ、観光収入による外货獾得の一翼を担う観光地としての 展開が期待されたいたのである。上高地は、当時の登山ブームが後押 しするかたちとなって、関東と関西の中間(横浜、神戸からの中間)に

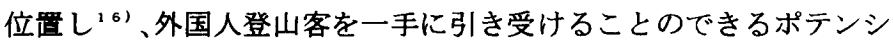
ヤルの高い観光地として認識されていたと思われる。

国際観光委員会第二部特別委員会第六回会議 (1931 年 9 月 16 日) で、国際観光局庶務課長長崎惣之助から、将来の山の在り方について の報告 ${ }^{11}$ とこれに関する議論が行われ、その話題は上高地の観光開 発が中心となった。これをうけて同局長新井克爾、国際観光委員会委 員で帝国ホテル会長大倉喜七郎、同委員で都ホテル会長藤村義郎、長 野県知事等が、上高地へ視察に訪れ、会議で上高地の開発手法に関す る各自の見解を示した ${ }^{18)}$ 。上高地の開発に対する彼らの構想は、具 体性を帯びたもので、外国人観光客を受け入れるための施設整備と して、新たなホテル施設と、アクセス道路の確保が検討された。

\section{2 滞在型钼光地形成のための宿泊施設整供}

新井の報告 ${ }^{9)}$ によると、当時の上高地には宿泊施設が三軒あり、 それぞれ以下の特長を持っていた。

$\begin{array}{ll}\text { 五千尺旅館 } & \text { 河童橋側で景色良好 } \\ \text { 上高地温泉ホテル } & \text { 温泉あり } \\ \text { 清水屋旅館 } & \text { 電気あり }\end{array}$

これらの施設は「三軒共ソレゾレ特徴ヨ持ツテ、商売敵トシテ椬 嘩」しており、「上高地ノ発展ノ上二大変困ル」とされ、委員の概ねの 意見としては、これらの施設の経営体質は、国際観光政策上、百害あ
つて一利なしと捉えられていた。また、新井は会議の席上、長野県に 対し、これらを「買収スルトカ、何トカシテ処理スル方法」を考案する ように要請し、宿泊施設整備と併せて道 路の問題 も検討させている ことも明らかにした。施設整備に際して 低利骶資等の必要性がある のならば、委員会として「何トカ考へテ見ヤウト云フコトヨ約束」す る等、いわば新井は既にこの地にホテル、道路を建設し、多数の観光 客を呼び 寄せ、長期滞在できるような一体的な開 発を行うことを構 想していたのである。

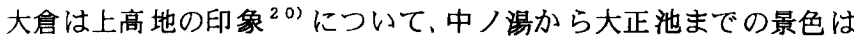
旧本在来ノ渓谷美」で、他の景勝地と変わらないものだが、大正池か ら先については、「全ク今マデ日本デ見マシタ景色トハ 違ツテ」いる として絶賛した。彼の言動からは上高地への有入れの様子が司え、上 高地の観 光開発に対して、ホテル事業者として積 極的に関与する準 備がある態 度をませるものだった。また、当時、上高地に建ち始め ていた「カフェー二類似」した店舖が林立していく様子に「俗化ノ方 ヘ行クノデハナイカ」と、吐露し、観光関連施設の質の低下を憂んだ。 また、大倉は上高地を開発する際、「ドウシテモーツノホテルハ必要」 21)であるとし，外国人観光客を受け入れる宿 泊施設の必要性を 訴え た。また、若者が上高地でキャンプを行うことは、保健衛生上、景観 上、好ましいことではなく、スチューデント・ルームを持ったホテ ル、ないしはバンガロー施設を整備する ことが適切である ${ }^{22)}$ とも指 摘した。大倉もまた、上高地の観光 開発に対する明快なヴィジョンを 抱いていたのである。

\section{3 アクセス道路建設案にみる委員の钼光開発に対する態度}

上高地への多くの来客を 可能とするための第一条件として、国際 観光委員会・第二 部特別委 員会第六 回会議では、特に自動 車道路整 備が検討された。本節では同会 議の議事からアクセス道路 建設案に みる委員の観光開発に対する態度を概観する。

前述のように電源開発に 伴う道路 整備は進行していたものの、観 光に供する道路、即ち、「自動車走行」に耐えるだけの道路整備は進展 しておらず，観光客の往来に不便をきたしていた。会議では、既に上 高地に外国人を宿泊させるだけのホテルを建設することが必要視さ れていたが、その建 設資材搬入やその後の利用客のためのアクセス

\begin{tabular}{|c|c|c|c|c|}
\hline 現 状 & 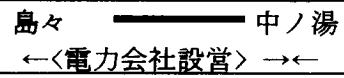 & $\begin{array}{l}\text { (釜隧道) } \\
<\text { 電力会社設営 }>\end{array}$ & $\begin{array}{l}\text { 大正池 } \\
\rightarrow \leftarrow\end{array}$ & 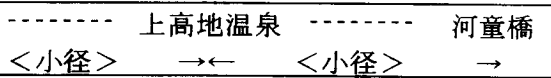 \\
\hline 鈴木石垣知事案 & $\begin{array}{l}\text { 島々 } \overline{\text { 中ノ湯 }} \\
\leftarrow\langle\text { 電力会社設営 }\rangle \rightarrow \leftarrow\end{array}$ & (県道移管後道路改良) & $\begin{array}{l}\text { 大正池 } \\
\rightarrow \leftarrow\end{array}$ & $\begin{array}{l}\text { 上高地温泉 } \\
\text { (小径を残して迁回路建設) }\end{array}$ \\
\hline 藤村委貣案 & $\begin{array}{l}\text { 島々 } \\
\leftarrow(\text { 自動車通行止 }) \rightarrow \leftarrow \\
\end{array}$ & (自動車通行止) & $\begin{array}{l}\text { 大正池 } \\
\rightarrow \leftarrow\end{array}$ & $<$ 小径 $>\quad$ 上高地温泉 $\quad \rightarrow$ 小 \\
\hline 大倉委員案 & 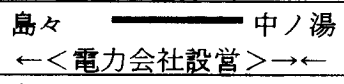 & (県道移金管後道道 & $\begin{array}{l}\text { 大正池 } \\
\rightarrow \leftarrow\end{array}$ & 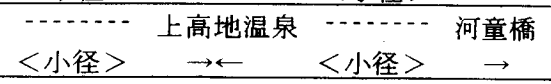 \\
\hline 藤村委員妥協案 & $\begin{array}{ll} & \text { 中ノ湯 } \\
\leftarrow \text { (舗装改良) } & \rightarrow \leftarrow \\
\end{array}$ & $\begin{array}{l}\text { 釜隧道 } \text { (具道移管後道路改良) } \\
\end{array}$ & $\begin{array}{l}\text { 大正池 } \\
\rightarrow \leftarrow \\
\end{array}$ & $\begin{array}{l}\text { 籠あるいはチェア高地温泉 } \\
\end{array}$ \\
\hline 実施された道路 & 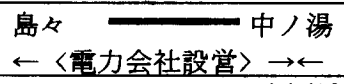 & (紧道移管後道路改良) & $\begin{array}{l}\text { 大正池 } \\
\rightarrow \leftarrow \\
\end{array}$ & （帝国ホテルにより別の道 \\
\hline
\end{tabular}

凡例 :

\begin{tabular}{|c|c|c|}
\hline & 自動車通行可能 & $\begin{array}{l}\text { (広偪員) } \\
\text { (狭幅員) }\end{array}$ \\
\hline$\cdots$ & 自動車通行不能 & （狭幅貣） \\
\hline & II & \\
\hline $\begin{array}{l}<\quad> \\
(\quad)\end{array}$ & $\begin{array}{l}\text { 現状維持 } \\
\text { 要改良 }\end{array}$ & \\
\hline
\end{tabular}

*本図は第二部特別委員会第六回会議において議論された各委員の道路整備案を図にしたも のである。国際観光局編 : 第二部特別委員会第六回会議礒事録、1931。

*道路改良の度合いについては、各委員の発言から、最も適切なレベルを判断した。

*鈴木石垣知事案は、「宿屋」まで迁回路を建設するとしている。宿屋は三軒存在したが、う ち二軒が上高地温泉側、一軒が河童橋側にあった。本稿では再遠方の河童橋までと判断した。 *大含案の発表は藤村の強硬な道路建設反対論の後のため、藤村に配慮して大正池までにし たと思われる。元来、大倉は「ホテル経営上道路ハ上ノ方マデ付ケ」るべき立場だった。 


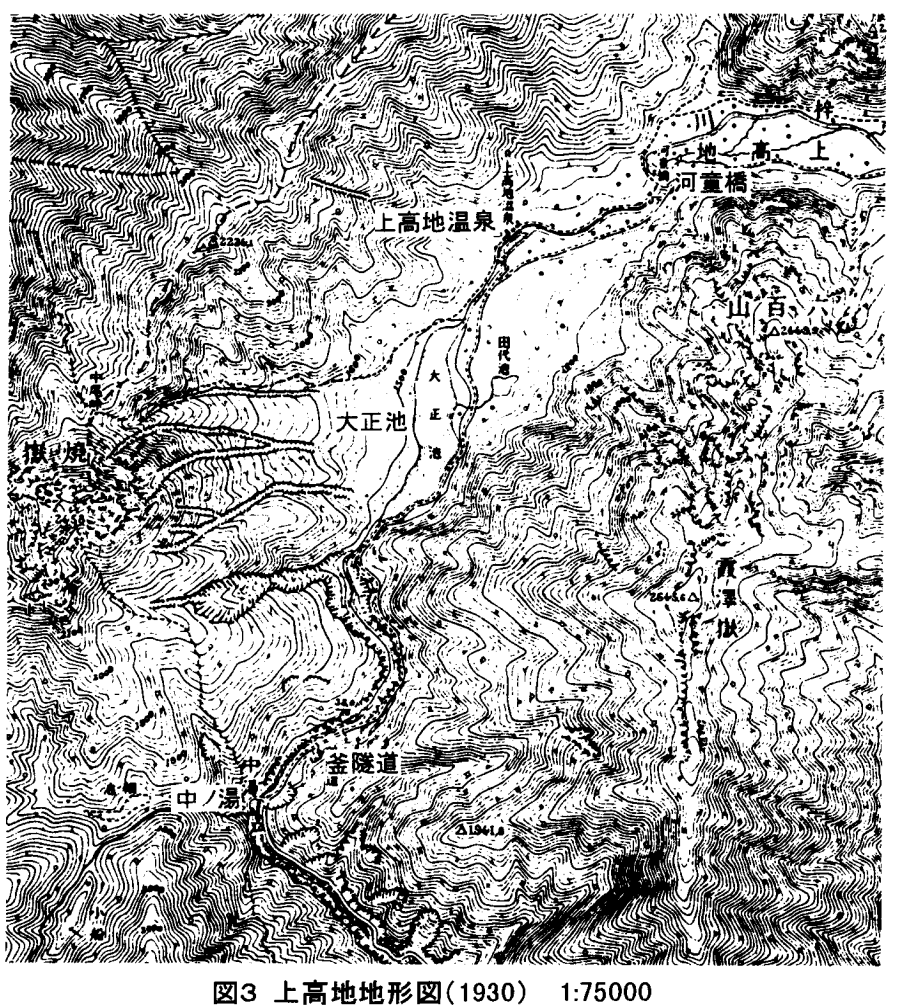

道路建設という側面からも道路整備に対する各委員の意見が闘わさ れた。その概要を要粎したのが図 2 である。大倉をはじめとする大半 の意見は、大正池までの自動車道路の整備を必要視しており、このこ とは藤村を除いて、コンセンサスが確立されていた。もはや、ことの 問題は自動車道をどこまで通すのかを、大正池までか、更に上高地温 泉までか、更に先の河童橋までかが検討されようとしていた。例え ば、長野県の鈴木、石垣両 知事の構 想は、最遠の河童橋まで 迂回路を 建設して、自動車道を延伸するべきだとしていた（図 2)。

しかし、藤村はこれらの一切の立場に強硬に反対した。藤村は，他 の委員より一足先に上高地に訪れ、松本から軌道が 通じている島々 から先は「自動車八無用」という印象を抱いていた。その理由として， 自動車の走行により 鹰を飛ばすとか、歩行客の邪魔になる点を挙げ ると同時に、ホテル建設やその経営上、荷物を運ぶための自動車道路 が必要だとした意見に対しても、「荷物ヨ運ブ便不便ト云フガ如キ問 題デハナイ」と言い切った。更に、「自動車デ以ツテホテルマテ横着々 ニシナケレバ気ガ済マヌト云フヤウナ御客サンハ、上高地へ 来テ蒷 ハナクテモ宜イ」と、実業家らしからぬ姿勢を露わにした。更に、自動 車が山深く分け入っていくことに関して、「ソレコソ山霊ガ何ト云フ コトカ」とまでも言った。だが、どうしても道路を建設することが避 けられないのならば、大正池までは自動 車が入れるようにすること は仕方ない(図 2、藤村妥協案) とした。とはいえ、大正池から先に関 しては「自動車ノ警笛ノ音ヨサセルト云フ其ノコトガ既二間違」って おり、閉漃の気分を台無しにするとして、断じて大正池より先の道路 建設を許すわけにはいかないという態度をとった。これに対する彼 の代替案として、大正池より先を連絡するのに「籠」或いは「チエヤ 一」の設備を施すことを提案した。当時の観光地開発が観光客の利便 性のみを踏まえた自動車道や軌道等の大量輸送手段整備を志向して いたことを考えるならば、彼の意見は観光資源である自然と人間の 行う観光行動との妥協点を探ったという点に於いて注目に値する。
大倉は、藤村の強硬な自動車 道建設反対 論の後にも、「大正池ノ辺 二自動車ノデクヨ造ツテ、ソコラ自動車ノ最終」としたいと念を押 し、自動車道建設は必要不可欠であるとの考えを示した。この議論の 展開から、国際観光局、長野県、大倉の三者と、藤村委員の間で上高地 開発に対する認識 の違いが 鮮明となった。県側は上高地の 開発に積 極的であり、大倉もまた、藤村に配虑したとはいえ、これに準じてい たのである。だが、藤村は、何よりも「自然习保持 維持シタイ」とする 立場から、開発には極めて慎重な姿勢をとるように主張していた。

上高地の観光開発を考えるとき、大倉らの立場は、開発に傾注した 態度であり、一方、藤村は、人やら車やらが山に入れば、如何せんとし ても、自然が失われてしまうという現実があるという「積極的な」反 開発論者であった。結局、大倉が率いる帝国ホテルが上高地にホテル を建設することになるのだが、この大倉、藤村の観光地開発に対する 態度の差が、彼らの国際観光政 策に伴う 国際観光 ホテル建 設事業に 関わる影度の差 ${ }^{23}$ に反映されたと考えられる ${ }^{24)}$

\section{4.長野県と大倉喜七郎による開発／国際観光地へ}

以上より、長野県 (以下、県) と大倉は上高地の全面的な観光地開 発 に乗り出したといっても語慗はないだろう ${ }^{25)}$ 。事実、県と帝国ホテ 儿は国際観光局等 政府関連機関と「上高地ホテル」 ${ }^{26)}$ 建設関連事業 に取り組み、上高地の観光開発は大きく前進した。当時の一連の観光 開発が、現在に至る観光地・上高地の形成を促したのである。以下に その詳細な開発の経過を概観する。

県による上高地へのホテル建設計画には、当初、県知事石垣倉治は 消極的だったが、新井らがホテル建設に䝷意を示して、石垣も建設に

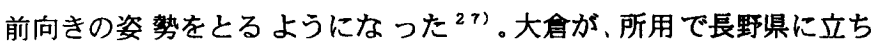
寄った際、石垣は正式にホテルの建設と経営委託を申し入れ、計画は 一気に進展した ${ }^{28)}$ 。その内容は、ホテルは長野県の所有とし、帝国木 テルは県 当局の委 託を受けて、その建設 と竣工後の経営を行うもの で、財源は国際観光局等の斡旋のもと、大蔵省からの低利融資を仰ぐ 計画であった ${ }^{29)}$ 。大倉は先にも見てきたように上高地に対して 詳細 な見聞をしており、上高地の観光地としての価値、必要とされるホテ ルの概要、アクセス道 路整備方 法を具体的に指摘していた。いわば、 県による ホテル建設の提案 は、大倉にとってリスクを負わない事業 拡大であり、歓迎すべきものであったといえよう。

1933 年 3 月 28 日、ホテル調查会において「上高地ホテル新設の 件 Jが付議決 定され、帝国ホテルと県の間に 仮契約が締 結され、翌月 5 日には、県知事石垣倉治の名のもと、大蔵省へ融資申請した ${ }^{30)}$ 。運 用委員会による融資の決定が同年 5 月 12 日に行われ、25 万円の融 資が決定 ${ }^{311}$ し、敖地は大 正池畔から田代橋を 経て河童橋に至る一帯 の中から、霞沢山簏に連なる中ノ瀬の高台 6,000 坪に見当をつけた ${ }^{32)}$ 。 5 月中には着工し、収容人員 200 人、総工费は 30 万円 (内 5 万円 を帝国ホテルが出資)で、設計は高 橋貞太郎、施工は大倉 土木の協力 の下、帝国ホテル直営で行われた ${ }^{33}$ 。大倉は帝国 ホテル会長である と同時に、大倉土木 (現・大成建設)の会長でもあり、ホテルの経営 と 建設を行える人物で、他の実業家とは一線を画した国際観光政策に よるホテル整備を強力に推進することのできる存在だった。

ところで、上高地ホテル建設に際す計画段階において、先に見た県 と大倉 (帝国ホテル)による道路整備が実施された。帝国ホテル支配 人の犬丸徹三も、中ノ湯温泉から釜檤道を経て大正池までの電力会 
社が建設した道路と、その先の上高地までの小径が、自動車通行に耐 えられるようなものに改修するべきであると 指摘した ${ }^{34)}$ 。このこと は県と帝国ホテルの交涉にも影響を与え、犬丸はホテル建設 の引き 替え条件として、県による釜馗よりホテル建設地に至る県道の改 良を挙げ ${ }^{35}$ ，県はこの意向を受けて、ホテル起工までに中ノ湯より 大正池に至る電力会社の私道を県に移管し、改修を行ったのである。 また、大倉の率いる帝国ホテルは上高地ホテルの建設資金の一部 (30 万円)をもって、大正池から中ノ瀬を過ぎて河 童橋に至る道路（費用 5 万円）を開堅して県に寄付し、この時から自動車による上高地入り が可能となったのである。このように、帝国ホテルと県が協力して上 高地周辺の道路整備を進展させたのである ${ }^{36)}$ (図 2 実施案)。

この過程において、藤村の意見は何ら反映されることはなかった。 その一因として、新規ホテル事 業の経営 者に帝国ホテルが選ばれた こともあるが、藤村が 1933 年 11 月に逝去したことが大きく起因し ていると思われる。

彼らによる道路整備により 1933 年には松本一上高地間にバスが 運行し始め、上高地への往来は誰にとっても容易なものとなり、上高 地の観光地化は頂点を迎えた。翌年の 1934 年には年間 53,629 人の 登山者が上高地を訪れた ${ }^{37 \text { 。 }}$

\section{5 結}

本報告は以下の点を明らかにした。

(1)都市部 の電力需要 の増加が 上高地周 辺のダム 建設を促 進し、これ に伴ってアクセス道 路が建設 され、上高地の観光地としての ポテン シャルは増大した。

(2)対外収 支改善のための外国 人観光客誘致政策（国立公園制 定運動 と国際観光政策の両側面から)で、上高地の観光開発の重要性が認識 された。

(3)国際観 光政策の関 係者の間で、上高地を国際的な水準を持った観 光地、マウンテンリソートにするための宿泊施設整 備の必要性が認 識され、宿泊施設整備 と観光に供するアクセス道路 建設が㲘 案事項 となった。

(4)上高地の観光開発には、国際観光委員会委員であり、帝国ホテル会 長であった大倉喜七 郎の意向と、観光地 整備を積極 的に推し 進めた 時代背景 (国際観光局 等の観光 関連機関 の存在とホテル建設 資金融 資制度の創設）が大きく寄与していた。

謝辞

本研究を進めるにあたり、加藤彰一豊橋技術科学大学助教授、西罣素彦名古屋 大学助教镹から貫重なご助言を頂いた。また、本研究の一部は笹川科学研究助成 金により行われた。記して感謝の意とします。

\section{琺注·券考文献}

1）政府は外客誘致に関する事項を司る中央機関として、1930年 4 月 24 日付勅 命第 83 号を以て鉄道省の外局として「国㮏䚁光局」を設嘈した。これに伴って、鉄 道大臣の詻問機関として 1930 年 7 月 2 日付勅令第 130 号により設圆されたのが 「国際観光委員会」である。これらの組織は国除観光を専門に扱う日本で初めての 政府機関であり、政策的に国除観光収入を増収に転じ、貿易収支を改善すること が期待された。同委員会の組織とその概要については、砂本文彦他 1 名 : 国際観 光委員会の組織 (讙問題一号関連) と国際稓光政策、建築学会東海支部研究報告集 第 35 号、pp.805 808、1997.2、に詳しい。ちなみに、国除観光委員会の英文名 は、財団法人国際絸光協会の機関誌、国除観光』 3 巻 2 号に収められている当時 の田諴国際锶光局長の英文奇稿文「Tourist Industry is Polygonal 」に国際観光委員 会を Committee of Tourist Industry と表記しており、拙稿もこれに準じた。

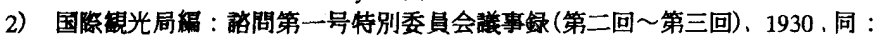

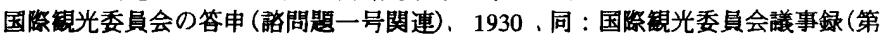

一回～第五回）、1930·1931，同：第一部特別委員会㦈事録（第一回～第六回） $1930 \cdot 1931$ 、同：第二部特別委員会議事録（第一回～第七回)、1930·1931、同：第 三部特別委員会議事録(第一回～第六回)、1930·1931，同：第四部特別委員会議 事録(第一回〜第五回)、1930·1931。これらの文献から、国際観光政策に関寸る総 体的な知見を得ている。

3）本報告で取り报う上高地に関する議諭は、主として、国除瀵光局編 : 第二部 特別委員会第六回会賸議事録、1931に収められている。

4) 月刊観光 1979 年 1 月号, pp.34 41

5）京浜電力の計画は堰提高 $45 \mathrm{~m}$ 、延長 $700 \mathrm{~m}$ の大計画で、ボーリング調查を行 う等実施段階に入っていたが、風最保绫の高まり(1924 年の庭園協会の意見書 等)から中止となった。梓川電力の計画も同様に風哀保茲の観点から樎小され、大 正池の現状を変えない㙘提が 1927 年に建設された。田中正大：日本の自然公園、 相模書房、p.229、1981

6）京浜電力，梓川奄力は梓川水系の電力を神奈川県に供給送電(送電は横浜電 気しててた。新田宗雄:東京電燈株式会社開業五十年史、東京電燈株式会社、1936 7) 注 4)に同じ。

8）丸山宏:近代日本公園史の研究、思文閣、p.302、1994

9）白馬山、日光、温泉ヶ岳、阿葆山も同年に調査が行われた。前掲書 8)、p.294

10）内務省衛生局編 : 国立公圆候補地調查概要、1930

11） 1934 年に中部山岳国立公園として指定された。

12）1931 年制定国立公園法理由書

13）上高地における微光開発計画か、国立公園法発布前の1920 年代に検討され た可能性は充分にある。だが、本稿では、現在へと引き継がれている上高地の観光 地形成に直接与えた影䇾を概観するために、次章に述べるような国除観光行政 側、国際観光委貣会を中心とした議論から上高地の形成を読み解くものとする。 14）昭和日本の新たな景勝地を見いだす運動である。東京日日新聞社、大阪毎日 新聞社主催、鉄道省後投で、投票総数は 9,348 万㗞にものぼった。1932 年 4 月に 日本新八景は発表された。なお、既に钼光地としての地位を獲得していた瀬戸内 海、琶笆湖、阿萑、富士山等は対象外とされた。東京日日新關社:東日七十年史、東 京日日新聞社, pp. $215 \sim 216 、 1941$

15）第三部特別委員会第二回会議にて公表された。

16）注 10)に同じ。

17） 1931 年 7 月に開催された「山の座談会」に関する報告。出席者は登山家や公 園行政関係者が含まれ、小島鳥水や東京営林局本多静六らがいた。前掲書 5)、 p.229

18）前揭書 3)

19）同上。

20）同上。

21）上高地一带は営林署の管轄だったため、許可がない限り新たな宿泊施設の 開業は困難だった。そのため三軒の旅館の宗占状態にあり、宿賃は高額であった。 22）第二部国除䚁光委員会第二回会議中で、大倉は湿気の多い上高地でのキャ ンプは腹痛をおこしやすいうえ、また、彼らは周辺にコミを散らかし、草を踏みに じるとした。従って、キャンプを行う客居が多い若者を収容するための低廉な宿 泊施設を確保すべきだとした。後に、上高地ホテルのスチューデント・ルームと して実現された。

23）大倉は後の大藏省預金部資金低利蝠資による 14 のホテル建設事業の、およ

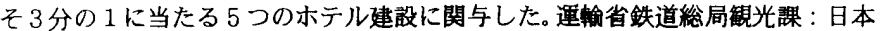
ホテル略史、 1946

24）ちなみに、国立公園行政側では、上高地の道路整備は「梓川治ヒノ自動車道 路习延長シ、大正池上流ニアリテハ両岸二分レ、河童橋ニテ会」すのが適切とされ た。国際観光委員会の議諭と歩調が舫っていることがわかる。前掲書 7)

25）また、新井の言動から判断する限り、彼が石垣知事と大倉にホテル建設への 協力要請をするよう進言した可能性も否定できない。

26）1936 年より上高地帝国ホテルと称す。

27）犬丸徹三 : ホテルと共に七十年、展望社、pp.244〜 245、1964

28）同上。

29）大藏省預金部資金を地方自治体が建設するホテルに限り融資する制度で、 その計画をホテル調查会、運用委貝会等が蕃滕し、地方自治体に融資された。 1932 年から 5 年間に 14 事業、総額 515 万円が骶資され、静岡県(川奈ホテル)、名 古屋市(名古屋観光ホテル)、栃木県 (日光観光ホテル、現中禅寺金谷ホテル)、長崎 県 (雲仙観光ホテル) 等がある。世界交通文化発達史、東京日日新聞社 pp.602 603,1940

30）帝国ホテル:帝国ホテル百年史、 p.317、1990

31）国際観光局編：国際観光事業概説，付表第七表、1934

32）前揭書 27)，p.247

33）前揭書 30), pp.316 317

34）前掲書 27)、 p.246

35） 中ノ湯から上高地ホテルまでの区間の大半が県の施工によると思われる。

36）前揭書 27)，p.248

37）大屋羡人：信州観光就本、長野新聞社、1937

[1997年 6 月11日原稿受理 1997年 9 月 1 日採用決定］ 